Pak. j. sci. ind. res. Ser. B: biol. sci. 2020 63B(3) 214-225

\title{
Temperature Regimes on Seeds Germination and Growth Parameters of Wheat (Triticum aestivum L.) Genotypes at Early Seedling Stage
}

\author{
Saquib Hussain ${ }^{\mathrm{a} *}$, Qamaruddin Chachar ${ }^{\mathrm{a}}$, Sadaruddin Chachar ${ }^{\mathrm{b}}$, Bahram Khan Chachar ${ }^{\mathrm{c}}$, \\ Wajid Ali Jatoid ${ }^{d}$, Muhammad Asif Siddiqui ${ }^{e}$ and Rafiq Ahmad Rindh ${ }^{b}$ \\ ${ }^{a}$ Department of Crop Physiology, Sindh Agriculture University Tandojam, Sindh, Pakistan \\ ${ }^{b}$ Department of Biotechnology, Sindh Agriculture University Tandojam, Sindh, Pakistan \\ 'Department of Animal Production, Lasbela University of Agriculture, Water and Marine Sciences, Uthal, \\ Balochistan, Pakistan \\ dDepartment of Plant Breeding and Genetics, Sindh Agriculture University Tandojam, Sindh, Pakistan \\ ${ }^{\mathrm{e}}$ Department of Soil Science, Sindh Agriculture University Tandojam, Sindh, Pakistan
}

(received October 5, 2018; revised March 4, 2019; accepted March 6, 2019)

\begin{abstract}
To observe the effect of high temperatures stresses i.e., normal $\left(25^{\circ} \mathrm{C}\right)$, high $\left(30^{\circ} \mathrm{C}\right)$ and very high $\left(35^{\circ} \mathrm{C}\right)$ stress, on germination and seedling growth on wheat genotypes a water culture study was conducted under controlled conditions (growth incubators). Eighteen newly developed wheat lines (DHI, DH-3, DH-4, DH-5, DH-6, DH-7, DH-8, DH-10, DH-11, DH-12, DH-13, DH-14, DH-15, DH-16, DH18, DH-19, DH-20 and DH-21) were tested along with two local checks i.e., Kiran-95 and LU-26s. There was a gradual reduction in germination and seedling growth at $30{ }^{\circ} \mathrm{C}$ and $35^{\circ} \mathrm{C}$. Among the tested genotypes the genotype $\mathrm{DH}-16$ showed least reduction i.e. only $2.27 \%$ reduction in germination at $35^{\circ} \mathrm{C}$. On the other hand the genotype DH-6 showed maximum reduction $(28.09 \%)$ at $35^{\circ} \mathrm{C}$. High temperature stresses also affected on other growth parameters i.e. shoot and root length $(\mathrm{cm})$, fresh and dry matter $(\mathrm{g})$ of shoot and root and the moisture contents. It is based on relative reduction over control in various growth parameters at very high temperature stress $\left(35^{\circ} \mathrm{C}\right)$, four genotypes viz., DH-3, DH-5, DH-8 and DH-13 appeared as tolerant, nine genotypes i.e., DH-1, DH-4, DH-7, DH-10, DH-11, DH-14, DH-18, and LU-26s appeared as medium tolerant and two as medium sensitive i.e. DH-6 and DH-16. On the other hand six genotypes viz., DH-12, DH-15, DH-19, DH-20, DH-21 and Kiran-95 showed sensitivity $35^{\circ} \mathrm{C}$ over $25{ }^{\circ} \mathrm{C}$. It is therefore concluded that the genotypes DH-3, DH-5 and DH-13 can be cultivated on heat prone areas of Pakistan especially in Sindh province.
\end{abstract}

Keywords: temperature, wheat, germination, early seedling, growth

\section{Introduction}

Wheat (Triticum aestivum L.) is the most widely cultivated cereal in the World. It is grown in a wide range of environments but thrives best in temperate zones where is adequate rainfall and temperature (Bibinu and Gwadi, 2014). Wheat grains are main cereal which provided protein, energy minerals and vitamins to most of the population (Ahmed and Hassan, 2015). Wheat production can be increased through plantation of productive genotype, which better adjust in an agroclimatic condition.

The selection for grain yield improvement can only be effective, if necessary genetic variability is present in breeding materials (Ali et al., 2008). Multifarious types of environmental conditions contribute to big yield losses as they cause change in metabolism, thereby *Author for correspondence; E-mail: ssaquibjan@yahoo.com trigging the entire crop physiology (Arshad et al., 2008; Monclus et al., 2006; Lichtenthaler 1998). The growth and development of wheat is highly affected through high temperature and causes low yield in many regions of the world (Modarresi et al., 2010). The environmental stress such as high temperature are major abiotic stresses which seriously affect crop production (Roza et al., 2010).

The seed germination is basic component which contributes fluctuation in yield of the crop (Zhixia et al., 2014).Germination is depended upon the capability of seeds to utilize reserves extra efficiently (Rao and Sinha, 1993), through mobilization (Penning et al., 1979). Temperature is the most important factor for seeds germination, whereas it increases the rate of water absorption and substrates source which are compulsory for growth and development (Essemine 
et al., 2002; Wanjura and Buxtor, 1972). The favourable temperature is excellent for germination, however both low and high temperature directly effect from seeds germination to seeds maturation (Khan et al., 2007; Lobell and Monasterio, 2007).

Doubled haploids (DH) wheat plant has complete homozygosity and one generation from hybrid plants, in this process includes two major steps: haploid induction and chromosome doubling. In both steps the plant routinely and successfully performed by using colchicines (Zhixia et al., 2014). However in haploid cause crop species varies in success and efficiency but higher plants can occur spontaneously. They can also be artificially induced in vivo or in vitro by and rogenesis and gynogenesis (Zhixia et al., 2014).

The variances of genetic characters in wheat varieties have greater magnitude than environmental variances for most of the traits (Ikramullah et al., 2011). Similarly, (Anwar et al., 2007) suggested that higher yield productivity could be made through better agronomic strategies and breeding materials, whereas (Cerriet et al., 2007) reported that 3 to $5{ }^{\circ} \mathrm{C}$ high temperature and $11 \%$ increase in precipitation would decrease the productivity of wheat. Keeping in view the above constraints, the present project was initiated with the objective to screen out wheat genotypes as sensitive and tolerant to heat stress conditions based on germination percentage (\%) and various allied physiological parameters against different temperature levels $(25,30$ and $35^{\circ} \mathrm{C}$ ) in water culture under controlled laboratory.

\section{Materials and Methods}

Eighteen newly developed wheat genotypes (i.e. DHI, DH-3, DH-4, DH-5, DH-6, DH-7, DH-8, DH-10, DH-11, DH-12, DH-13, DH-14, DH-15, DH-16, DH18, DH-19, DH-20, DH-21), along with two commercial varieties(Kiran-95 and LU-26s) as local checks were studied for their high temperature tolerance at germination and early seedling stage. The study was conducted in water culture, using $1 / 4^{\text {th }}$ strength Hoagland nutrient solution (Hoagland and Arnon, 1950) as cultural media in plastic molded bowls having nets $(5 \mathrm{~cm}$ internal diameter and $2.5 \mathrm{~cm}$ depth). The chemical composition of Hoagland nutrient solution is presented in Table 1. Healthy seeds of all the wheat genotypes were surface sterilized for five minutes with $2.0 \% \mathrm{NaOH}$ (sodium hypochlorite) and then washed thoroughly with distilled water to avoid any contamination. Thirty (30) seeds of each genotype were laid on plastic nets and the bowls were kept in dark in programmed controlled three separate growth incubators (Luminine cube II, ANALIS Model, LM-500), each one is pre adjusted at 25, 30 and $35{ }^{\circ} \mathrm{C}$ temperature treatments, respectively. The bowls were arranged in randomized manner using completely randomized design (CRD), with three replicates. The level of nutrient solution maintained regularly throughout the experiment. Germination was recorded after $72 \mathrm{~h}$ and then light programme was activated up to the termination of experiment for further seven (7) days and the experiment was terminated at after 10 days. Growth observations were recorded in terms of germination percentage, shoot and root length, fresh and dry weights of shoot and root. Germination percentage (\%) was recorded after 24 hours, using the following formula:

$$
\text { Germination }(\%)=\frac{\text { no. of seeds germinated }}{\text { total no. of seeds sown }} \times 100
$$

The shoot and root length was measured by ruler in centimeter $(\mathrm{cm})$ at the time of termination of experiment. Fresh weight of shoot and root was also recorded immediately in grams using electronic balance. Plant samples (shoot and root) were placed in hot air drying oven $\left(65 \pm 5^{\circ} \mathrm{C}\right)$ for $72 \mathrm{~h}$ to take shoot and root dry weights in gram $(\mathrm{g})$ with electronic digital balance. Relative reduction in different growth parameters were calculated as:

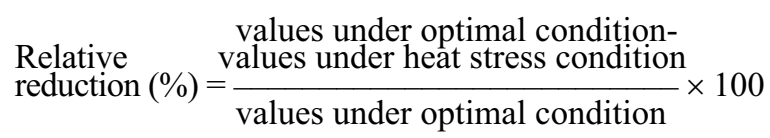

$\begin{aligned} & \text { Shoot and root } \\ & \text { moisture contents }(\%)\end{aligned}=\frac{\text { F. wt. }- \text { D. wt. }}{\text { F. wt. }} \times 100$

Temperature stress indexes (germination stress index, shoot length stress index and root length stress index) were also calculated according to (Ashraf et al., 2008), using following formulas:

$$
\begin{aligned}
& \text { GSI }=\frac{\text { PI of stress seeds }}{\text { PI of control seeds }} \times 100 \\
& \text { SLSI }=\frac{\text { shoot length of stressed plant }}{\text { shoot length of control plants }} \times 100 \\
& \text { RLSI }=\frac{\text { root length of stressed plant }}{\text { root length of control plants }} \times 100
\end{aligned}
$$


The data was subjected to analysis of variance (ANOVA) and significant difference were measured according to Duncan multiple range test (DMRT), using Statixtic 8.1 , computer package.

\section{Results and Discussion}

The mean square from analysis of variances showed that genotypes, treatments and genotypes x treatments were significant for all the traits (Table 2a) which indicated that genotypes performed differently across the temperature regimes. Our results are confirmed with Sikder and Paul (2010) they also reported that the wheat genotypes performed differently under different temperature for germination percentage, shoot/root fresh weight, shoot/root dry weight.

Seed germination (\%). The present results showed that seed germination under different temperature was significantly reduced (Table $2 \mathrm{~b}$, column A). At $25^{\circ} \mathrm{C}$ the genotypes like DH-10, DH-11, DH-14 and DH-15 recorded highest that is $100 \%$ seed germination and minimum $(91.11 \%)$ seed germination was given by DH-4. At $30{ }^{\circ} \mathrm{C}$, the maximum seed germination was 98.88\% (DH-11 and DH-15), that showed at par response of statistically with DH-1, DH-5, DH-6, DH-14, DH19 and DH-21 which had $97.77 \%$ seed germination, respectively. The minimum $(86.66 \%)$ seed germination was observed in DH-4. At $35{ }^{\circ} \mathrm{C}$ the maximum seed germination was recorded in genotype DH16 i.e., $95.55 \%$, while minimum seed germination was observed in genotype DH-6 i.e., $71.11 \%$. The mean seed germina- tion was observed to be $98.00 \%$ at $25{ }^{\circ} \mathrm{C}(95.44 \%)$ followed by $300 \mathrm{C}(95.44 \%)$ and $35^{\circ} \mathrm{C}(85.12 \%)$. It is evident from the result that a significant decreasing trend in germination percenage was observed as the temperatures increased (Table 2b, Column A, last row). The present findings can partially be compared with Buriro et al. (2011) who reported more than $90 \%$ germination at $10-30{ }^{\circ} \mathrm{C}$. The maximum percentage reduction in seed germination was $28.09 \%$ at $35^{\circ} \mathrm{C}$ over $25^{\circ} \mathrm{C}$ in DH-6 followed by DH-13, DH-7, DH21, DH-12, DH-15, and DH-1 with 26.13, 21.35, 20.23, $19.10,16.67$ and $15.73 \%$ reduction, respectively. The present findings can be compared safely with those of Sikder and Paul (2010) who evaluated three temperature levels $\left(16,26\right.$ and $\left.36^{\circ} \mathrm{C}\right)$ on germination rate in wheat cultivars and reported an increasing trend in germination at 16 to $26^{\circ} \mathrm{C}$ and respiration loss increased at higher temperatures $\left(26-36^{\circ} \mathrm{C}\right)$.

Shoot fresh weight (g). The shoot fresh weight was reduced significantly at $30^{\circ} \mathrm{C}$ and $35^{\circ} \mathrm{C}$ as compared to $25{ }^{\circ} \mathrm{C}$ in all the genotypes. The temperature effect on cumulative basis revealed significant difference (Table 2b, column B). Mean shoot fresh weight was recorded as $4.01 \mathrm{~g}$ in $25^{\circ} \mathrm{C}$ whereas, the lowest 1.81 $\mathrm{g}$ in $35{ }^{\circ} \mathrm{C}$ treatment. At $25^{\circ} \mathrm{C}$ the genotype DH-5 showed maximum shoot fresh weight i.e. $4.83 \mathrm{~g}$; however the genotype DH-18 showed minimum shoot fresh weight i.e. $3.45 \mathrm{~g}$ and was statistically at par with $\mathrm{DH}-$ 15 i.e. 3.48 g. At $30{ }^{\circ} \mathrm{C}$ the shoot fresh weight was recorded as maximum in $\mathrm{DH}-4$ (3.39 g) while minimum

Table 1. Chemical composition of Hoagland nutrient solution

\begin{tabular}{|c|c|c|c|}
\hline \multicolumn{4}{|l|}{ A. Macro nutrients } \\
\hline Compound & Formula & $\begin{array}{l}\text { Stock solution } \\
(\mathrm{g} / \mathrm{L})\end{array}$ & $\begin{array}{l}\text { Stock solution }(\mathrm{cc}) \\
(\mathrm{mL})\end{array}$ \\
\hline Potassium nitrate & $\mathrm{KNO}_{3}$ & 101 & 12 \\
\hline Calcium nitrate & $\mathrm{Ca}\left(\mathrm{NO}_{3}\right)_{2} 4 \mathrm{H}_{2} \mathrm{O}$ & 236 & 08 \\
\hline Ammonium phosphate & $\mathrm{NH}_{4} \mathrm{H}_{2} \mathrm{PO}_{4}$ & 115 & 04 \\
\hline Magnesium sulphate & $\mathrm{MgSO}_{4} 7 \mathrm{H}_{2} \mathrm{O}$ & 246 & 02 \\
\hline \multicolumn{4}{|l|}{ B. Micronutrients } \\
\hline Potassium chloride & $\mathrm{KCl}$ & 0.37 & 2 \\
\hline Boric acid & $\mathrm{H}_{3} \mathrm{BO}_{3}$ & 0.15 & 2 \\
\hline Manganese sulphate & $\mathrm{MnSO}_{4} \mathrm{H}_{2} \mathrm{O}$ & 0.03 & 2 \\
\hline Zinc sulphate & $\mathrm{ZnSO}_{4} 7 \mathrm{H}_{2} \mathrm{O}$ & 0.06 & 2 \\
\hline Copper sulphate & $\mathrm{CuSO}_{4} 5 \mathrm{H}_{2} \mathrm{O}$ & 0.01 & 2 \\
\hline Molybalic acid & $\mathrm{MO}_{4}$ & 0.01 & 2 \\
\hline Iron sulphate & $\mathrm{FeSO}_{4} 7 \mathrm{H}_{2} \mathrm{O}$ & 0.05 & 2 \\
\hline
\end{tabular}


value was observed in genotype DH-7 (1.82 g). At 35 ${ }^{\circ} \mathrm{C}$ the shoot fresh weight was recorded as maximum in DH-5 (2.87 g), while minimum value was observed in genotype Lu-26s (1.11 g). The maximum percentage reduction in shoot fresh weight was $73.25 \%$ in LU-26s at $35{ }^{\circ} \mathrm{C}$ over $25{ }^{\circ} \mathrm{C}$ whereas showed minimum shoot fresh weight was i.e. $37.09 \%$ in DH-4. The present findings can be compared in broader sense with those of Cerri et al. (2007) who reported that increase in temperature above threshold would cause decline in agricultural production. The present research achievements are in close conformity with Khajam et al. (2011), Akbar and Jaime (2012) and Lack et al. (2013) who reported that heat stress conditions exerted adverse effects on the biological growth of wheat.

Shoot dry weight $(\mathrm{g})$. It is evident from the results (Table 2b. column C) the shoot dry weight was significantly affected under different temperature levels. The mean shoot dry weight was recorded high value in 25 ${ }^{\circ} \mathrm{C}(0.38 \mathrm{~g})$ followed in $30^{\circ} \mathrm{C}(0.33 \mathrm{~g})$ and $35^{\circ} \mathrm{C}(0.26 \mathrm{~g})$, respectively. At $25^{\circ} \mathrm{C}$ that $\mathrm{DH}-3$ showed maximum shoot dry weight i.e. $0.46 \mathrm{~g}$, while the genotype DH20 had minimum shoot dry weight i.e. $0.29 \mathrm{~g}$ and did not show significant difference with those of found on DH-7, DH-12 and DH-21 with 0.31 g shoot dry weight in each. At $30{ }^{\circ} \mathrm{C}$ the genotype $\mathrm{DH}-3$ was recorded maximum shoot dry weight i.e. $0.45 \mathrm{~g}$, while $\mathrm{DH}-7$ showed minimum shoot dry weight i.e. 0.25 g. At 35 ${ }^{\circ} \mathrm{C}$ the maximum shoot dry weight was recorded in $\mathrm{DH}-$ $5(0.38 \mathrm{~g})$, whereas LU-26s and Kiran-95 showed minimum shoot dry weight ( $0.10 \mathrm{~g}$ each). The minimum reduction in shoot dry weight was recorded as $6.45 \%$ in DH-12, whereas maximum i.e. $51.28 \%$ in Kiran-95 at $35^{\circ} \mathrm{C}$ over $25^{\circ} \mathrm{C}$ treatment. The present findings are not in conformity with those of Tahir et al. (2008) who stated that shoot growth was not affected at high root zone temperature. According to Sikder and Paul (2010) they reported that shoot dry weight increased at 16 to $26^{\circ} \mathrm{C}$ as compared to $26-36^{\circ} \mathrm{C}$.

Root fresh weight (g). Based on interactional response, among genotypes and temperatures, the root fresh weight decreased significantly on increasing temperature (Table 2c, column D), the on an average mean effect of various temperatures revealed significant differences. The maximum $(2.65 \mathrm{~g})$ root fresh weight was recorded in $25^{\circ} \mathrm{C}$, whereas minimum $(0.75 \mathrm{~g})$ root fresh weight was noted in $35^{\circ} \mathrm{C}$. Among the genotypes, DH-19 exhibited maximum $(3.77 \mathrm{~g})$ root fresh weight observed

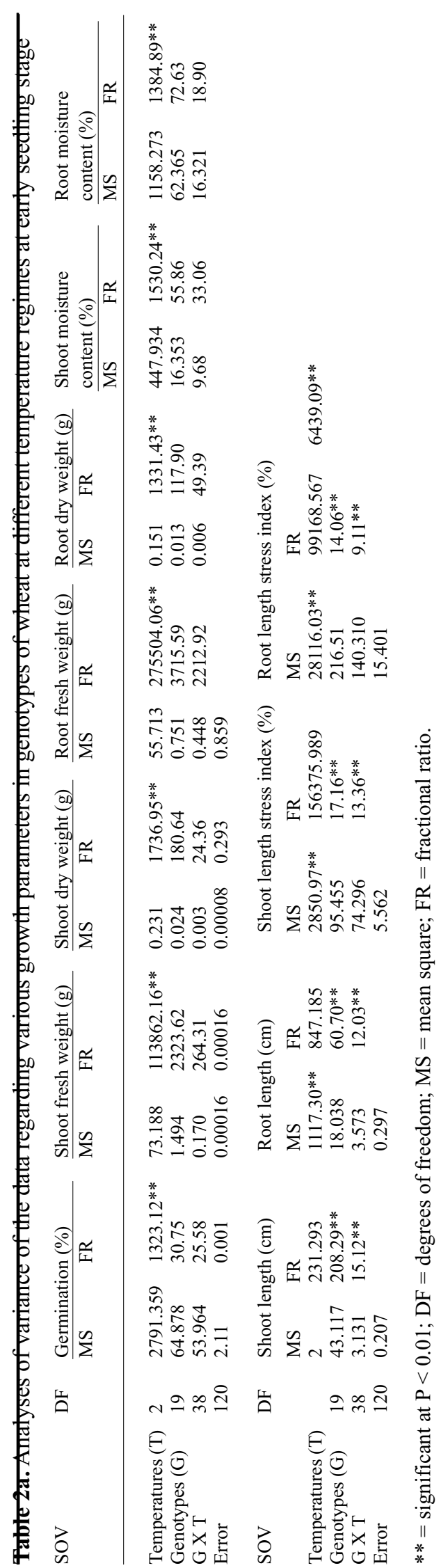


in $25^{\circ} \mathrm{C}$, and fluctuated significantly in all other genotypes and temperature treatments whereas, the genotype DH-7 showed minimum root fresh weight i.e. $2.02 \mathrm{~g}$ in $25^{\circ} \mathrm{C}$ treatment and also differed significantly from other treatments as well as genotypes. The maximum reduction of $86.14 \%$ in root fresh weight was recorded in LU-26s at $35{ }^{\circ} \mathrm{C}$ over $25^{\circ} \mathrm{C}$, while DH-3 showed minimum $(44.19 \%)$ reduction in root fresh weight at $35^{\circ} \mathrm{C}$ over $25^{\circ} \mathrm{C}$. Present result is suggested that increase in temperature which resulted significant decrease in root fresh weight. Our findings are in conformity with Anwar et al. (2000) and Tahir et al. (2008) who observed that maximum reduction in root length and weight was noted under high root zone temperature.

Root dry weight (g). The different temperature regimes cause significant reduction in root dry weight (Table $2 \mathrm{c}$ column E). Based on interactional responses, among the genotypes, the mean wise maximum $(0.21 \mathrm{~g})$ root dry weight was recorded at $25^{\circ} \mathrm{C}$ which is significantly reduced in $30^{\circ} \mathrm{C}$ and $35^{\circ} \mathrm{C}$ with 0.14 and $0.12 \mathrm{~g}$ in root dry weight, respectively. DH-16 showed maximum root dry weight of $0.34 \mathrm{~g}$ at $25{ }^{\circ} \mathrm{C}$ which is fluctuate statistically in all the other genotypes in same treatment as well as in other treatments like $30^{\circ} \mathrm{C}$ and $35^{\circ} \mathrm{C}$. The minimum $(0.12 \mathrm{~g})$ root dry weight was noted in $\mathrm{DH}-$ 7 at $25^{\circ} \mathrm{C}$, while other genotypes like DH-10, DH-12, DH-13, DH-4 and DH-3 they did not show significant differences at $30{ }^{\circ} \mathrm{C}$ treatment their root dry weight ranged from 0.13 to $0.15 \mathrm{~g}$. The root dry weight was significantly reduced at $35^{\circ} \mathrm{C}$ in all the genotypes. DH15 showed maximum reduction in root dry weight i.e. $70.97 \%$ at $35^{\circ} \mathrm{C}$ over $25{ }^{\circ} \mathrm{C}$. The minimum reduction of $15.38 \%$ in root dry weight was recorded in genotypes DH-10 and DH-13. The present findings are in conformity with Sikder and Paul (2010) who reported that at higher temperature like $26-36^{\circ} \mathrm{C}$, root dry weight was dramatically reduced. Camacho and Caraballo (1994) reported that root dry weight was identified as

Table 2b. Temperatures effect on plant growth parameters in various genotypes of wheat under water culture experiment from column A to $\mathrm{C}$

\begin{tabular}{|c|c|c|c|c|c|c|c|c|c|c|c|c|}
\hline \multirow{3}{*}{$\begin{array}{l}\text { Geno- } \\
\text { types }\end{array}$} & \multicolumn{4}{|c|}{ Seed germination $(\%)(\mathrm{A})$} & \multicolumn{4}{|c|}{ Shoot fresh weight (g) (B) } & \multicolumn{4}{|c|}{ Shoot dry weight (g) (C) } \\
\hline & \multicolumn{3}{|c|}{$\begin{array}{l}\text { Interactional response } \\
(\mathrm{LSD} \text { at } 5 \%=2.34)\end{array}$} & \multirow{2}{*}{$\begin{array}{l}(\%) \mathrm{Re}- \\
\text { duction } \\
\text { at } 35^{\circ} \mathrm{C} \\
\text { over } 25^{\circ} \mathrm{C}\end{array}$} & \multicolumn{3}{|c|}{$\begin{array}{l}\text { Interactional response } \\
(\mathrm{LSD} \text { at } 5 \%=0.05)\end{array}$} & \multirow{2}{*}{$\begin{array}{l}(\%) \mathrm{Re}- \\
\text { duction } \\
\text { at } 35^{\circ} \mathrm{C} \\
\text { over } 25^{\circ} \mathrm{C}\end{array}$} & \multicolumn{3}{|c|}{$\begin{array}{c}\text { Interactional response } \\
(\mathrm{LSD} \text { at } 5 \%=1.445 \mathrm{E}-02)\end{array}$} & \multirow{2}{*}{$\begin{array}{l}(\%) \mathrm{Re}- \\
\text { duction } \\
\text { at } 35^{\circ} \mathrm{C} \\
\text { over } 25^{\circ} \mathrm{C}\end{array}$} \\
\hline & $25^{\circ} \mathrm{C}$ & $30^{\circ} \mathrm{C}$ & $35^{\circ} \mathrm{C}$ & & $25^{\circ} \mathrm{C}$ & $30^{\circ} \mathrm{C}$ & $35^{\circ} \mathrm{C}$ & & $25^{\circ} \mathrm{C}$ & $30{ }^{\circ} \mathrm{C}$ & $35^{\circ} \mathrm{C}$ & \\
\hline DH-1 & $98.89 \mathrm{AB}$ & $97.77 \mathrm{ABC}$ & $83.33 \mathrm{M}$ & 15.73 & $4.61 \mathrm{~B}$ & $2.90 \mathrm{OP}$ & $2.25 \mathrm{~W}$ & 51.19 & $0.42 \mathrm{C}$ & $0.37 \mathrm{GH}$ & $0.32 \mathrm{MNO}$ & 23.81 \\
\hline DH-3 & 95.55 CDE & 94.44 DEF & 89.99 HIJ & 5.82 & $4.66 \mathrm{~B}$ & $3.39 \mathrm{~K}$ & $2.65 \mathrm{~S}$ & 43.13 & $0.46 \mathrm{~A}$ & $0.45 \mathrm{AB}$ & $0.37 \mathrm{HI}$ & 19.57 \\
\hline DH-4 & $91.11 \mathrm{GHI}$ & $86.66 \mathrm{KL}$ & $83.33 \mathrm{M}$ & 8.54 & $4.26 \mathrm{C}$ & $3.09 \mathrm{M}$ & $2.68 \mathrm{RS}$ & 37.09 & $0.40 \mathrm{EF}$ & $0.40 \mathrm{DEF}$ & $0.37 \mathrm{HI}$ & 7.50 \\
\hline DH-5 & $98.89 \mathrm{AB}$ & $97.77 \mathrm{ABC}$ & $86.67 \mathrm{KL}$ & 12.36 & $4.83 \mathrm{~A}$ & $3.34 \mathrm{~L}$ & $2.87 \mathrm{P}$ & 40.58 & $0.45 \mathrm{AB}$ & $0.41 \mathrm{CDE}$ & $0.38 \mathrm{GH}$ & 17.78 \\
\hline DH-6 & $98.89 \mathrm{AB}$ & $97.77 \mathrm{ABC}$ & $71.11 \mathrm{O}$ & 28.09 & $4.15 \mathrm{D}$ & $2.53 \mathrm{~T}$ & 1.33 & 67.95 & $0.44 \mathrm{~B}$ & $0.35 \mathrm{JK}$ & $0.29 \mathrm{PQR}$ & 34.09 \\
\hline DH-7 & $98.88 \mathrm{AB}$ & $92.22 \mathrm{FGH}$ & $77.77 \mathrm{~N}$ & 21.35 & $3.75 \mathrm{H}$ & 1.82 & 1.39 & 62.93 & $0.31 \mathrm{NOP}$ & $0.25 \mathrm{~T}$ & 0.21UVW & 32.26 \\
\hline DH-8 & $97.77 \mathrm{ABC}$ & 95.55 CDE & $85.55 \mathrm{LM}$ & 12.50 & $3.58 \mathrm{I}$ & $2.38 \mathrm{~V}$ & $1.90 \mathrm{Z}$ & 46.93 & $0.37 \mathrm{GH}$ & $0.29 \mathrm{QR}$ & $0.25 \mathrm{~T}$ & 32.43 \\
\hline DH-10 & $100.00 \mathrm{~A}$ & $92.22 \mathrm{FGH}$ & $91.11 \mathrm{GHI}$ & 8.89 & $3.92 \mathrm{~F}$ & $2.95 \mathrm{O}$ & $2.45 \mathrm{U}$ & 37.50 & $0.39 \mathrm{~F}$ & $0.33 \mathrm{~L}$ & $0.30 \mathrm{OPQ}$ & 23.08 \\
\hline DH-11 & $100.00 \mathrm{~A}$ & $98.88 \mathrm{AB}$ & $85.55 \mathrm{LM}$ & 14.45 & $4.23 \mathrm{C}$ & $3.03 \mathrm{~N}$ & $2.06 \mathrm{Y}$ & 51.30 & $0.37 \mathrm{GH}$ & $0.37 \mathrm{GHI}$ & 0.33 LM & 10.81 \\
\hline DH-12 & $98.88 \mathrm{AB}$ & $96.66 \mathrm{BCD}$ & $79.99 \mathrm{~N}$ & 19.10 & $3.70 \mathrm{H}$ & $2.78 \mathrm{Q}$ & 1.74 & 52.97 & $0.31 \mathrm{NOP}$ & $0.30 \mathrm{PQR}$ & $0.29 \mathrm{PQR}$ & 6.45 \\
\hline DH-13 & $97.77 \mathrm{ABC}$ & 94.44 DEF & $72.22 \mathrm{O}$ & 26.13 & $3.82 \mathrm{G}$ & $2.87 \mathrm{P}$ & $2.18 \mathrm{X}$ & 42.93 & $0.39 \mathrm{~F}$ & $0.32 \mathrm{LMN}$ & $0.29 \mathrm{QR}$ & 25.64 \\
\hline DH-14 & $100.00 \mathrm{~A}$ & $97.77 \mathrm{ABC}$ & $91.11 \mathrm{GHI}$ & 8.89 & $3.58 \mathrm{I}$ & $2.47 \mathrm{U}$ & $1.26 \mathrm{a}$ & 64.80 & $0.36 \mathrm{HIJ}$ & $0.27 \mathrm{~S}$ & $0.21 \mathrm{WX}$ & 41.67 \\
\hline DH-15 & $100.00 \mathrm{~A}$ & $98.88 \mathrm{AB}$ & $83.33 \mathrm{M}$ & 16.67 & $3.48 \mathrm{~J}$ & $2.13 \mathrm{X}$ & 1.39 & 60.06 & $0.45 \mathrm{AB}$ & $0.31 \mathrm{OPQ}$ & $0.22 \mathrm{U}$ & 51.11 \\
\hline DH-16 & $97.77 \mathrm{ABC}$ & $96.66 \mathrm{BCD}$ & $95.55 \mathrm{CDE}$ & 2.27 & $4.07 \mathrm{E}$ & $2.72 \mathrm{R}$ & 1.63 & 59.95 & $0.39 \mathrm{FG}$ & $0.32 \mathrm{MNO}$ & $0.21 \mathrm{UV}$ & 46.15 \\
\hline DH-18 & 96.77BCD & $92.22 \mathrm{FGH}$ & 89.99 HIJ & 7.01 & $3.45 \mathrm{~J}$ & $2.27 \mathrm{~W}$ & $1.12 \mathrm{~b}$ & 67.54 & $0.34 \mathrm{KL}$ & $0.29 \mathrm{QR}$ & $0.21 \mathrm{Y}$ & 37.62 \\
\hline DH-19 & $98.88 \mathrm{AB}$ & $97.77 \mathrm{ABC}$ & 88.88 IJK & 10.11 & $4.25 \mathrm{C}$ & $2.88 \mathrm{P}$ & 1.77 & 58.35 & $0.41 \mathrm{CD}$ & $0.30 \mathrm{OPQ}$ & $0.20 \mathrm{VWX}$ & 51.22 \\
\hline DH-20 & $97.77 \mathrm{ABC}$ & $96.66 \mathrm{BCD}$ & $86.66 \mathrm{KL}$ & 11.36 & $3.57 \mathrm{I}$ & $2.46 \mathrm{U}$ & 1.33 & 62.75 & $0.29 \mathrm{PQR}$ & $0.28 \mathrm{RS}$ & $0.17 \mathrm{Y}$ & 41.38 \\
\hline DH-21 & $98.88 \mathrm{AB}$ & $97.77 \mathrm{ABC}$ & $78.88 \mathrm{~N}$ & 20.23 & $3.90 \mathrm{~F}$ & $2.44 \mathrm{U}$ & 1.53 & 60.77 & $0.31 \mathrm{NOP}$ & $0.29 \mathrm{PQR}$ & $0.20 \mathrm{VWX}$ & 35.48 \\
\hline LU26s & $94.44 \mathrm{DEF}$ & $91.11 \mathrm{GHI}$ & $87.99 \mathrm{JKL}$ & 6.83 & $4.15 \mathrm{D}$ & $2.68 \mathrm{RS}$ & $1.11 \mathrm{~b}$ & 73.25 & $0.36 \mathrm{IJ}$ & $0.32 \mathrm{LMN}$ & $0.19 \mathrm{WX}$ & 47.22 \\
\hline Kiran-95 & $98.88 \mathrm{AB}$ & $95.55 \mathrm{CDE}$ & $93.33 \mathrm{EFG}$ & 5.61 & $4.18 \mathrm{D}$ & $2.81 \mathrm{Q}$ & 1.63 & 61.00 & $0.39 \mathrm{FG}$ & $0.29 \mathrm{PQR}$ & $0.19 \mathrm{X}$ & 51.28 \\
\hline Means & $98.00 \mathrm{~A}$ & $95.44 \mathrm{~B}$ & $85.12 \mathrm{C}$ & & $4.01 \mathrm{~A}$ & $2.70 \mathrm{~B}$ & $1.81 \mathrm{C}$ & & $0.38 \mathrm{~A}$ & $0.33 \mathrm{~B}$ & $0.26 \mathrm{C}$ & \\
\hline $\begin{array}{l}(\mathrm{LSD} \\
\text { at } 5 \%)\end{array}$ & & 0.52 & & & & 1.14 & & & & $3.23 \mathrm{E}-03$ & & \\
\hline
\end{tabular}

The mean in the same column and the same rows sharing the same letters did not differ significantly. 
the major criterion for selection of wheat genotypes under temperature stress conditions.

Shoot moisture content (\%). The Table 2 c. of column $\mathrm{F}$, showed that different temperature regimes caused lower in shoot moisture content. Further results revealed at room temperature i.e. $25{ }^{\circ} \mathrm{C}$ showed highest (90.48\%) shoot moisture contents whereas minimum (85.01\%) shoot moisture contents was recorded at $35{ }^{\circ} \mathrm{C}$. The genotype like DH-21 showed maximum (92.16\%) shoot moisture content which was at par statistically with DH-7, DH-20, LU-26s and DH-12 having 91.74, $91.65,91.44$ and $91.61 \%$ moisture contents in $25^{\circ} \mathrm{C}$, respectively. The minimum shoot moisture content was $81.92 \%$ in DH-15 and differed significantly in all other genotypes at $25^{\circ} \mathrm{C}$. A significant reduction in shoot moisture content was recorded in $30{ }^{\circ} \mathrm{C}$ and $35^{\circ} \mathrm{C}$ treatments in all the genotypes with more or less variation. The shoot moisture content percentage reduction decreased as the temperature increased. DH6 showed maximum reduction i.e. $14.36 \%$ in $35^{\circ} \mathrm{C}$ over $25{ }^{\circ} \mathrm{C}$. The minimum reduction of shoot moisture content i.e., $1.64 \%$ was observed in $\mathrm{DH}-19$ in $35{ }^{\circ} \mathrm{C}$ over $25^{\circ} \mathrm{C}$ treatments. Okçu et al. (2005) reported that temperature stresses depressed the shoot growths of the cultivars rather than their root growth. Walters (1998) reported that temperature and moisture play a significant role in determining the storage longevity of seeds.

Root moisture contents (\%). Based on interactional response among genotypes and various temperatures, the Table $2 \mathrm{~d}$. column $\mathrm{G}$, showed that on an average mean of all the genotypes under various temperature treatment like $25^{\circ} \mathrm{C}, 30{ }^{\circ} \mathrm{C}$ and $35^{\circ} \mathrm{C}$, the treatment one $\left(25^{\circ} \mathrm{C}\right)$ showed maximum $(92.10 \%)$ root moisture content whereas in treatment three $\left(35^{\circ} \mathrm{C}\right)$ the root moisture content was reduced in minimum i.e. $83.49 \%$. The treatment two $\left(30^{\circ} \mathrm{C}\right)$ showed intermediate trend having $89.32 \%$ root moisture contents and differed significantly from other treatment. It is evident that maximum root moisture content was observed on DH5 i.e. $94.46 \%$ and did not differ significantly with $\mathrm{DH}-$ 1, DH-3, DH-4, DH-7, DH-8, DH-11, DH-12 and DH13 having 93.44, 93.01, 92.70, 94.23, 93.40, 93.26, 93.15 and $93.02 \%$ root moisture contents, respectively in $25^{\circ} \mathrm{C}$. The minimum root moisture content was $90.30 \%$ in DH-16 and differed significantly in all other genotypes at $25^{\circ} \mathrm{C}$. The percentage reduction in root moisture at $35^{\circ} \mathrm{C}$ over $25^{\circ} \mathrm{C}$ revealed that the genotype $\mathrm{DH}-18$ possessed maximum root moisture $(22.12 \%)$ followed by DH-14, LU-26s and Kiran-95 with 15.47 , 13.83 and $13.41 \%$, respectively. Sikder and Paul (2010) also reported higher root moisture contents percentage at optimum temperature in wheat. Mahan et al. (1995) observed that thermal stress influence morphology and physiology of the root system which may influence water movement through the plant.

Shoot length $(\mathbf{c m})$. The shoot length was reduced significantly at $30{ }^{\circ} \mathrm{C}$ and $35^{\circ} \mathrm{C}$ as compared to $25^{\circ} \mathrm{C}$ in all the genotypes (Table $2 \mathrm{~d}$. column $\mathrm{H}$ ). Mean shoot length at $25^{\circ} \mathrm{C}$ was recorded as $18.43 \mathrm{~cm}$ and was reduced to 17.50 and $14.66 \mathrm{~cm}$ at $30^{\circ} \mathrm{C}$ and $35^{\circ} \mathrm{C}$, respectively. The genotype LU-26s possessed maximum shoot length $22.02 \mathrm{~cm}$ in $25^{\circ} \mathrm{C}$ and the minimum shoot length was found to be $14.43 \mathrm{~cm}$ in $\mathrm{DH}-8$. In $30^{\circ} \mathrm{C}$ the minimum shoot length was $11.51 \mathrm{~cm}$ in $\mathrm{DH}-7$ and the maximum is 21.68 in LU-26s. In $35^{\circ} \mathrm{C}$ which showed minimum $10.89 \mathrm{~cm}$ shoot length and the maximum is 19.71 in LU-26s. Based on percentage reduction in 35 ${ }^{\circ} \mathrm{C}$ over $25^{\circ} \mathrm{C}$, it is evident that the genotype DH- 6 and DH-3 showed maximum reduction in shoot length i.e. 36.83 and $30.86 \%$, respectively. The present findings can be compared in big sense with those of Hasan et al. (2004) also reported that from a low temperature to high temperature $\left(15\right.$ to $\left.30^{\circ} \mathrm{C}\right)$, the shoot length of wheat seedlings showed an increasing tendency.

Root length (cm). The results regarding the effect of different temperature on the root length (Table $2 \mathrm{~d}$. column I) revealed that maximum average mean root length was recorded in $25^{\circ} \mathrm{C}$ treatment $(15.72 \mathrm{~cm})$, while it was minimum in $35^{\circ} \mathrm{C}$ treatment i.e. $8.24 \mathrm{~cm}$. the root length was $12.64 \mathrm{~cm}$ in $30{ }^{\circ} \mathrm{C}$ and all the treatments differed significantly with one another. At $25{ }^{\circ} \mathrm{C}$, genotype $\mathrm{DH}-21$ showed maximum root length i.e. $17.22 \mathrm{~cm}$, while the genotype DH-6 and DH-10 possessed minimum root length showing 13.73 and $13.60 \mathrm{~cm}$. All other genotypes were found intermediate between maximum and minimum. The effect of $35^{\circ} \mathrm{C}$ on the root length was more pronounced as compared to $30{ }^{\circ} \mathrm{C}$ and $25^{\circ} \mathrm{C}$ treatments. The maximum percentage reduction in root length was recorded to be $62.00 \%$ in genotype DH-6 in $35^{\circ} \mathrm{C}$ over $25^{\circ} \mathrm{C}$. The minimum root length reduction was recorded to be $37.35 \%$ in $\mathrm{DH}-14$ in $35^{\circ} \mathrm{C}$ over $25^{\circ} \mathrm{C}$. The present findings support the results of present experiment with Sikder and Ahmed (2007) also found that root length of different wheat genotypes failed to increase under higher temperature $\left(32^{\circ} \mathrm{C}\right)$. 


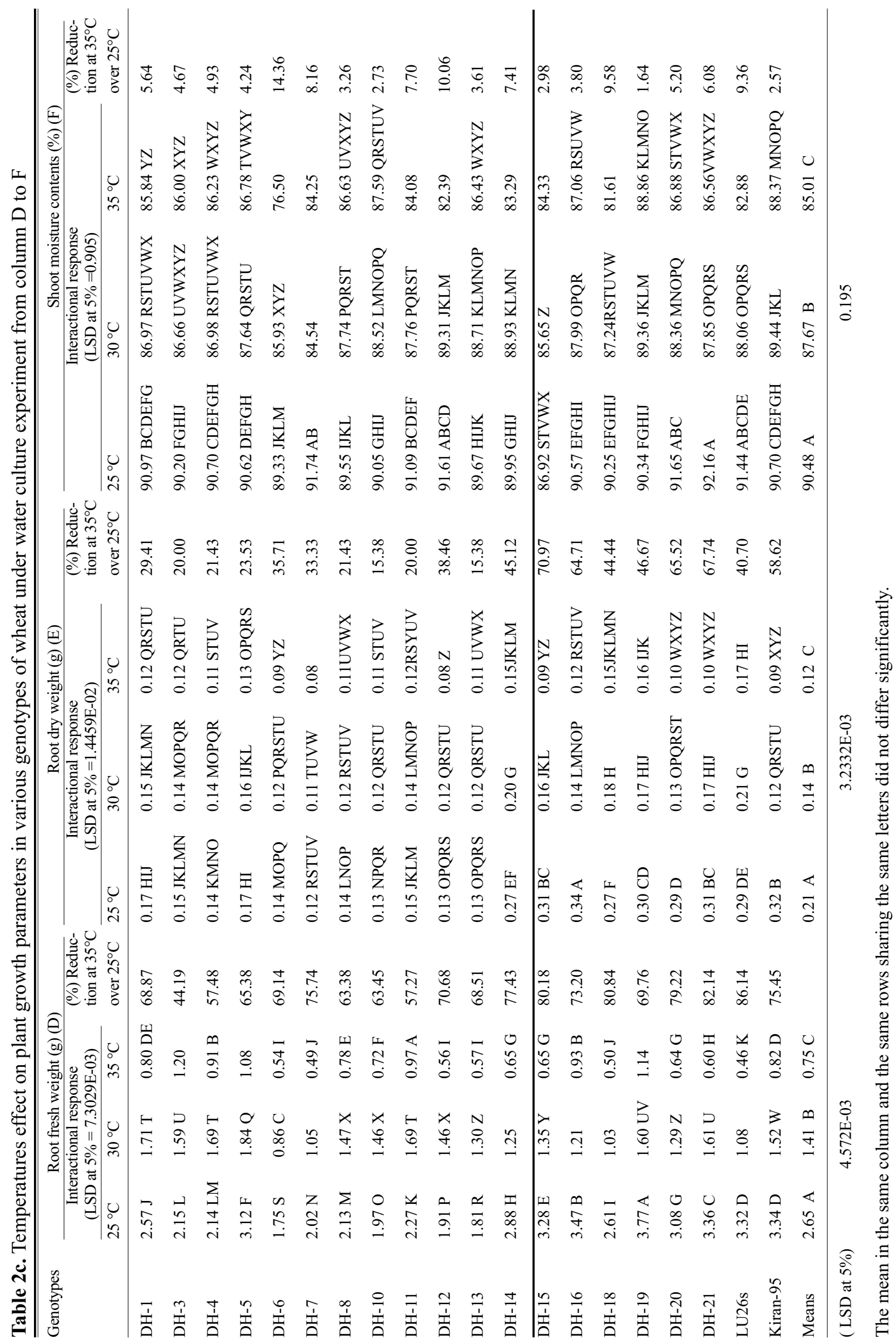




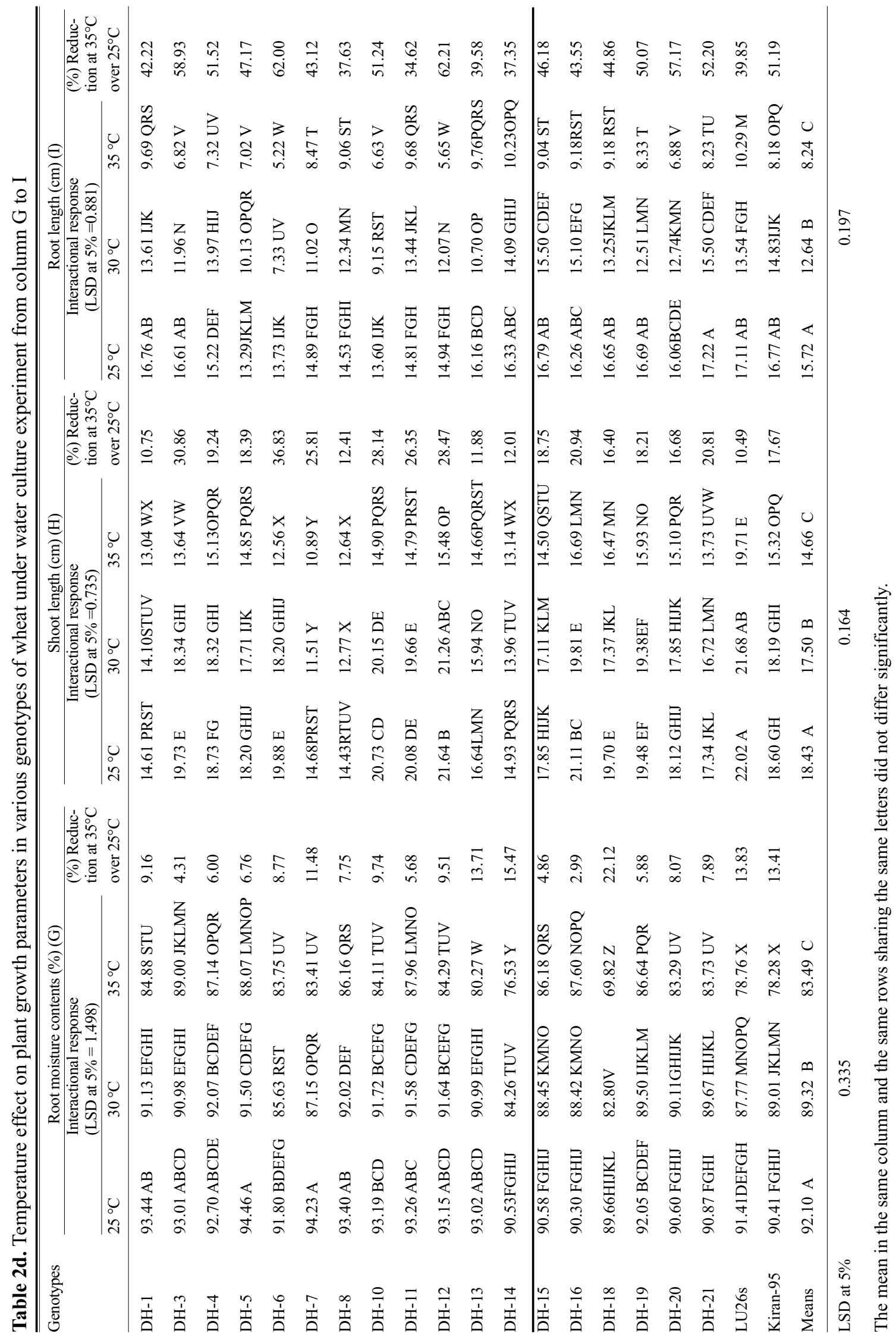


Shoot length stress index (\%). The Table 3, of column A, showed that if the temperature increases that causes significantly reduction in shoot length stress index (SLSI) further it was evidence from the mean results which showed that $30{ }^{\circ} \mathrm{C}$ showed SLSI i.e. $94.59 \%$ whereas minimum i.e. $80.60 \%$ SLSI in $35^{\circ} \mathrm{C}$ treatment. The genotype DH-20 had maximum SLSI i.e. $98.49 \%$ and the minimum SLSI was $78.38 \%$ in DH-7 in $30{ }^{\circ} \mathrm{C}$. The results obtained in $30{ }^{\circ} \mathrm{C}$ fluctuated significantly from $35{ }^{\circ} \mathrm{C}$ for all the genotypes with more or less variation. In $35^{\circ} \mathrm{C}$ minimum SLSI was $63.29 \%$ in DH6 and differed significantly from all other genotypes. The reduction percentage in SLSI in $35^{\circ} \mathrm{C}$ over $30^{\circ} \mathrm{C}$ revealed that the maximum reduction of $30.96 \%$ was found in DH-6 followed by DH-12, DH-10, DH-3 and DH-11 showing $27.28,26.01,25.65$ and $24.79 \%$ in SLSI, respectively. The minimum reduction was $1.01 \%$ in DH-8. The (\%) reduction in SLSI was ranged from 4.87 to 17.88 in other genotypes. According to Guedes et al. (2011), higher temperature $\left(35^{\circ} \mathrm{C}\right)$ can cause disintegration of protein structures and along with the toxic effect and physiological drought, led to reduction in shoot.

Root length stress index (\%). The average mean performance (Table 3 column B) regarding the root length stress index (RLSI) under different temperatures treated as treatments showed that the mean RLSI at 30 ${ }^{\circ} \mathrm{C}$ was $80.15 \%$ which was reduced to 51.54 at $35^{\circ} \mathrm{C}$, respectively. It is evident that the maximum RLSI (92.97\%) was observed in DH-16 at $30{ }^{\circ} \mathrm{C}$ and the minimum RLSI was recorded to be $53.50 \%$ in DH-6 and had significant difference from all other genotypes. The RLSI at $35^{\circ} \mathrm{C}$ treatment varied significantly among genotypes and was significantly lower than $30^{\circ} \mathrm{C}$ treatment in all the genotypes. The minimum RLSI at $35{ }^{\circ} \mathrm{C}$ was found to be $37.80 \%$ in $\mathrm{DH}-12$ and the maximum value was observed in DH-14 i.e., $62.72 \%$ RLSI. The (\%) reduction in RLSIs for each genotype of wheat in $35^{\circ} \mathrm{C}$ over $30^{\circ} \mathrm{C}$ revealed that the genotype DH-12 showed maximum reduction i.e., $53.22 \%$ followed by $47.66,46.87,45.99,44.79$ and $43.02 \%$ in

Table 3. Stress indices for shoot and root length in different genotypes of wheat under different temperature treatments

\begin{tabular}{|c|c|c|c|c|c|c|c|c|}
\hline \multirow[t]{2}{*}{ Genotypes } & \multicolumn{3}{|c|}{$\begin{array}{c}\text { Shoot length stress index }(\%)(\mathrm{A}) \\
\text { Interactional response } \\
(\mathrm{LSD} \text { at } 5 \%=3.812)\end{array}$} & \multirow{2}{*}{$\begin{array}{l}(\%) \\
\text { Reduction } \\
\text { at } 35^{\circ} \mathrm{C} \text { over } \\
30{ }^{\circ} \mathrm{C}\end{array}$} & \multicolumn{3}{|c|}{$\begin{array}{l}\text { Root length stress index }(\%)(B) \\
\text { Interactional response } \\
(\mathrm{LSD} \text { at } 5 \%=6.344)\end{array}$} & \multirow{2}{*}{$\begin{array}{l}(\%) \\
\text { Reduction } \\
\text { at } 35^{\circ} \mathrm{C} \\
\text { over } 30^{\circ} \mathrm{C}\end{array}$} \\
\hline & $25^{\circ} \mathrm{C}$ & $30^{\circ} \mathrm{C}$ & $35^{\circ} \mathrm{C}$ & & $25^{\circ} \mathrm{C}$ & $30^{\circ} \mathrm{C}$ & $35^{\circ} \mathrm{C}$ & \\
\hline DH-1 & $0 \mathrm{~S}$ & $96.48 \mathrm{ABCD}$ & $91.96 \mathrm{EFGH}$ & 7.63 & $0 \mathrm{Q}$ & $81.24 \mathrm{CD}$ & 57.85 IJKL & 28.79 \\
\hline DH-3 & $0 \mathrm{~S}$ & $93.02 \mathrm{CDEFG}$ & $69.16 \mathrm{Q}$ & 25.65 & $0 \mathrm{Q}$ & $72.03 \mathrm{EFG}$ & $41.04 \mathrm{P}$ & 43.02 \\
\hline DH-4 & $0 \mathrm{~S}$ & $97.80 \mathrm{AB}$ & 81.44 KLMN & 17.41 & $0 \mathrm{Q}$ & $91.88 \mathrm{AB}$ & $48.09 \mathrm{NO}$ & 47.66 \\
\hline DH-5 & $0 \mathrm{~S}$ & $97.34 \mathrm{ABC}$ & 82.95 KLM & 16.10 & $0 \mathrm{Q}$ & $76.21 \mathrm{DE}$ & $52.86 \mathrm{LMN}$ & 30.64 \\
\hline DH-6 & $0 \mathrm{~S}$ & $91.67 \mathrm{EFGH}$ & $63.29 \mathrm{R}$ & 30.96 & $0 \mathrm{Q}$ & 53.50 MNOP & $38.06 \mathrm{P}$ & 28.87 \\
\hline DH-7 & $0 \mathrm{~S}$ & $78.38 \mathrm{NO}$ & $74.19 \mathrm{P}$ & 5.35 & $0 \mathrm{Q}$ & $74.08 \mathrm{DEF}$ & 57.13 IJKLM & 22.88 \\
\hline DH-8 & $0 \mathrm{~S}$ & $88.47 \mathrm{HI}$ & $87.58 \mathrm{HIJ}$ & 1.01 & $0 \mathrm{Q}$ & $84.95 \mathrm{BC}$ & $62.42 \mathrm{HIJ}$ & 26.52 \\
\hline DH-10 & $0 \mathrm{~S}$ & 97.17 ABCD & $73.73 \mathrm{P}$ & 26.01 & $0 \mathrm{Q}$ & $67.43 \mathrm{FGH}$ & $48.78 \mathrm{NO}$ & 27.65 \\
\hline DH-11 & $0 \mathrm{~S}$ & $97.88 \mathrm{AB}$ & $74.61 \mathrm{OP}$ & 24.79 & $0 \mathrm{Q}$ & $91.03 \mathrm{AB}$ & 56.26 IJKLM & 38.20 \\
\hline DH-12 & $0 \mathrm{~S}$ & $98.26 \mathrm{AB}$ & $71.55 \mathrm{PQ}$ & 27.28 & $0 \mathrm{Q}$ & $80.82 \mathrm{CD}$ & $37.80 \mathrm{P}$ & 53.22 \\
\hline DH-13 & $0 \mathrm{~S}$ & $95.84 \mathrm{ABCDE}$ & $88.99 \mathrm{GH}$ & 8.03 & $0 \mathrm{Q}$ & $66.23 \mathrm{GH}$ & 60.53 HIJK & 8.60 \\
\hline DH-14 & $0 \mathrm{~S}$ & $92.80 \mathrm{DEFG}$ & $88.03 \mathrm{HI}$ & 5.14 & $0 \mathrm{Q}$ & $86.31 \mathrm{ABC}$ & $62.72 \mathrm{HI}$ & 27.33 \\
\hline DH-15 & $0 \mathrm{~S}$ & $95.88 \mathrm{ABCDE}$ & $81.89 \mathrm{KLMN}$ & 15.27 & $0 \mathrm{Q}$ & $92.48 \mathrm{~A}$ & $53.85 \mathrm{KLMN}$ & 41.77 \\
\hline DH-16 & $0 \mathrm{~S}$ & $93.79 \mathrm{BCDEF}$ & $79.06 \mathrm{MN}$ & 15.70 & $0 \mathrm{Q}$ & $92.97 \mathrm{~A}$ & 56.42 IJKLM & 39.31 \\
\hline DH-18 & $0 \mathrm{~S}$ & $87.88 \mathrm{HI}$ & $83.60 \mathrm{JKL}$ & 4.87 & $0 \mathrm{Q}$ & $79.62 \mathrm{CD}$ & 55.20 IJKLMN & 30.68 \\
\hline DH-19 & $0 \mathrm{~S}$ & $97.80 \mathrm{AB}$ & 83.34 KLM & 16.37 & $0 \mathrm{Q}$ & $75.04 \mathrm{DE}$ & 49.96 LMNO & 33.42 \\
\hline DH-20 & $0 \mathrm{~S}$ & $98.49 \mathrm{~A}$ & $84.33 \mathrm{IJK}$ & 15.41 & $0 \mathrm{Q}$ & $79.34 \mathrm{CD}$ & $42.85 \mathrm{OP}$ & 45.99 \\
\hline DH-21 & $0 \mathrm{~S}$ & $96.14 \mathrm{ABCD}$ & 79.72 LMN & 17.88 & $0 \mathrm{Q}$ & $90.04 \mathrm{AB}$ & $47.84 \mathrm{NO}$ & 46.87 \\
\hline LU26s & $0 \mathrm{~S}$ & $98.48 \mathrm{~A}$ & $90.15 \mathrm{FGH}$ & 9.09 & $0 \mathrm{Q}$ & 79.27 CD & 60.33HIJK & 23.89 \\
\hline Kiran-95 & $0 \mathrm{~S}$ & $97.82 \mathrm{AB}$ & $82.33 \mathrm{KLMN}$ & 15.84 & $0 \mathrm{Q}$ & $88.44 \mathrm{AB}$ & $48.83 \mathrm{NO}$ & 44.79 \\
\hline Means & $0.00 \mathrm{C}$ & $94.59 \mathrm{~A}$ & $80.60 \mathrm{~B}$ & & $0.00 \mathrm{C}$ & $80.15 \mathrm{~A}$ & $51.94 \mathrm{~B}$ & \\
\hline (LSD at 5\%) & & 0.85 & & & & 1.41 & & \\
\hline
\end{tabular}

The mean in the same column and the same rows sharing the same letters did not differ significantly. 
DH-4, DH-21, DH-20, Kiran-95 and DH-3, respectively. The minimum reduction in RLSI was observed in DH-13 i.e., $8.60 \%$. The other genotypes had intermediate trend with a range of 28.87 to $41.77 \%$ reduction in RLSIs. The present findings can compared with Leishman and Westoby (1994) the root length is an important trait against temperature stress in plant varieties; in general, variety with longer root growth has resistant ability for temperature.

Categorization of wheat genotypes based on $<\mathbf{5 0 \%}$ reduction in variables Studied at $35^{\circ} \mathrm{C}$ over $25^{\circ} \mathrm{C}$. The results (Table 4 and 5) obtained from the variables already studied in Table 2 a,b,c is summarized based on $<50 \%$ reduction at $35{ }^{\circ} \mathrm{C}$ over $25{ }^{\circ} \mathrm{C}$ reveal that out of 20 genotypes, four genotypes viz., DH-3, DH-5, DH8 and DH-13 appeared as tolerant in which these genotypes showed $<50 \%$ reduction in 10 variables. The nine genotypes i.e., DH-1, DH-4, DH-7, DH-10, DH11, DH-14, DH-18 and LU-26s were medium tolerant as these showed $<50 \%$ reduction in nine variables. The genotypes viz., DH-6 and DH-16 were medium sensitive because there were eight variables which showed $<50 \%$ reduction in these genotypes. Finally, there were six genotypes viz., DH-12, DH-15, DH-19, DH-20, DH21 and Kiran-95 which had sensitive response as 6 to 7 variables showed $<50 \%$ reduction in these genotypes to $35^{\circ} \mathrm{C}$ over $25^{\circ} \mathrm{C}$.

All the genotypes showed good performance on $25^{\circ} \mathrm{C}$ as compared 30 and $35^{\circ} \mathrm{C}$. These findings are in conformity with Modarries et al. (2010) who reported that temperature stress adversely affected wheat development and growth. Similar finding are also reported by (Essemine et al., 2002; Parera and Cantliffe 1994; Rao and Sinha, 1993; Penning et al., 1979; Wanjura and Buxtor, 1972). The present findings cannot be compared with those of Khajam et al. (2011) and Mukhtar and Hassan (2011) who studied the effect of temperature and solar radiation on the yield components causes significantly reduction in yield and yield related traits rather than plant growth parameters. The present findings can partially be compared with those of Akbar and Jaime (2012) who reported that wheat varieties when sown late (December 27) faced severe temperature stress and significantly affected phenology, growth and yield.

Table 4. Wheat genotypes categorized on the bases of $<50 \%$ reduction at low temperature levels

\begin{tabular}{llllllllllllllll}
\hline \hline Genotypes & G $\%$ & SFW & SDW & RFW & RDW & SMC & RMC & SL & RL & SLSI & RLSI & No. of \\
& & & & & & & & & & & & & \\
variables
\end{tabular}

G \% = germination \% age; SFW = shoot fresh weight; SDW = shoot dry weight; RFW = root fresh weight; RDW = root dry weight; SMC = shoot moisture content; RMC = root moisture content; SL = shoot length; RL = root length; SLSI = shoot length stress index; RLSI = root length stress index; + = genotypes showing $<50 \%$ reduction in variables; $-=$ genotypes showing $>50 \%$ reduction in variables. 
Table 5. Catagorization of wheat genotypes based on tolerance levels at $<50 \%$ reduction in growth parameters at early seedling stage

\begin{tabular}{lll}
\hline \hline Categories & Based on & Genotypes \\
\hline Tolerant & $<50 \%$ reduction in 10 variables & DH-3, DH-5, DH-8, DH-13 (04) \\
Medium Tolerant & $<50 \%$ reduction in 9 variables & DH-1, DH-4, DH-7, DH-10, DH-11, DH-14, DH-18, Lu26s (08) \\
Medium Sensitive & $<50 \%$ reduction in 8 variables & DH-6, DH-16 (02) \\
Sensitive & $<50 \%$ reduction in 7\&6 variables & DH-12, DH-15, DH-19, DH-20, DH-21, Kiran-95 (06) \\
\hline \hline
\end{tabular}

Wheat genotypes tested for temperature tolerance based on $<50 \%$ reduction at $35^{\circ} \mathrm{C}$ (early seedling studies); Genotypes tested $=20$; Tolerant genotypes $=04$; Medium Tolerant $=08$; Medium sensitive $=02$; Sensitive $=06$.

\section{Conclusion}

The present results based on the genotypes like DH-3, DH-5, DH- 8 and DH-13 were categorized as heat tolerant and other genotypes such as DH-1, DH-4, DH7, DH-10, DH-11, DH-14, DH-18 and LU-26s were medium tolerant, these genotypes could be grown under high temperature with minimum yield losses.

\section{Acknowledgment}

The first author in thankful to Higher Education Commission of Pakistan (HEC) for the award of indigenous scholarship for $\mathrm{PhD}$.

Conflict of Interest. The authors declare no conflict of interest.

\section{References}

Ahmed, M., Hassan, F. 2015. Response of spring wheat (Triticum aestivum L.) quality traits and yield to sowing date. Plos One. 1-16. (doi: 10. 1371/journal. pone.0126097).

Akbar, H., Jaime, A. 2012. Phenology growth and yield of three wheat (Triticum aestivum L.) varieties as affected by high temperature stress. Notulae Scientia Biologica, 4: 97-109.

Ali, M.A., Nawab, N.N., Rasool, G., Saleem, M. 2008. Estimates of variability and correlations for quantitative traits in (Cicer arietinum L). Journal of Agricultural and Social Sciences, 4: 177-179.

Anwar, M.R., Garry, O.L., David, M., Hemayet, H., Roger, N. 2007. Climate change impact on rainfed wheat in south-eastern Australia. Field Crops Research, 104: 139-147.

Arshad, M., Anwar, H., Ashraf, M.Y., Noureen, S., Moazzam, M. 2008. Edaphic factors and distribution of vegetative in the Cholistan Desert. Pakistan Journal of Botany, 40: 1923-1931.

Ashraf, M.Y., Hussain, F., Akhtar, J., Gul, A., Ross, M., Ebert, G. 2008. Effect of different sources and rates of nitrogen and supra optimal level of potassium fertilization on growth, yield and nutrient. Pakistan Journal of Botany, 40: 1521-1531.

Bibinu, A.T.S., Gwadi, K.W. 2014. Performance of some elite spring wheat genotypes under irrigation at Kirenowa, Borno state, Nigeria. Journal of Biology and Agricultural and Healthcare, 2: 42-47.

Buriro, M., Oad, F.C., Keerio, M.I., Tunio, S., Gandhahi, A.W., Hassan, S.W., Oad, S.M. 2011. Wheat seed germination under influence of temperature regimes. Sarhad Journal of Agricultural, 27: 44-65.

Camacho, R.G., Caraballo, D.F. 1994. Evaluation of morphological characteristics in Venezuelan maize (Zea mays L.) genotypes under drought stress. Scientia Agricola, 51: 453-458.

Cerrit, C.E.P., Gerd, S., Martial, B., Willian, E., Jerry, M., Clemente, C.C. 2007. Tropical agriculture and global warming: Impacts and mitigation options. Scientia Agricola, 64: 83-99.

Essemine, J., Ammar, S., Jbir, N., Bouzid, S. 2002. Sensitivity of two wheat species seeds (Triticum durum, variety Karim and Triticum aestivum, variety Salambo) to heat constraint during germination. Pakistan Journal of Biological Sciences, 10: 37623768.

Gill, H.S., Singh, A., Sethi, S.K., Behl, R.K. 2004. Phosphorus uptake and use efficiency in different varieties of bread wheat (Triticum aestivum). Archives of Agronomy and Soil Sciences, 50: 563-572.

Guedes, R.S., Alves, E.U., Galindo, E.A., Barrozo, L.M. 2011. Stress saline and temperaturas on germination vigor desementes de Chorisia glaziovii O. Kuntze. Revista Brasileira de Sementes, 33: 279-288.

Hasan, M.A., Ahmed, J.U., Hossain, T., Hossain, M.M., Ullah, M.A. 2004. Germination characters and seed reserves mobilization during germination of different wheat genotypes under variable temperature regimes. Journal of Natural Sciences, Foundation Srilanka, 32: 97-107. 
Ikramullah, I.H.K., Rahman, H., Mohammad, F., Ullah, H., Khalil, S.K. 2011. Magnitude of heritability and selection response for yield traits in wheat under two different environments. Pakistan Journal of Botany, 43: 2359-2363.

Khajam, S., Sharmai, S.N., Sharma, Y. 2011. Effect of high temperature on yield attributing traits in bread wheat. Bangladesh Journal of Agricultural Research, 36: 415-426.

Khan, I., Khalil, I.H., Nasir-ud-din. 2007. Genetic parameters for yield traits in wheat under irrigated and rain fed environments. Sarhad Journal of Agricultural, 23: 1016-4383.

Khan, A.H., Ashraf, M.Y., Azmi, A.R. 1990. Effect of $\mathrm{NaCl}$ on growth and nitrogen metabolism of sorghum. Acta Physiologiae Plantarum, 12: 233238.

Lack, S., Zarei, B., Kamali, M.R.J., Naderi, A., Modhej, A. 2013. Determination of physiological traits related to terminal drought and heat stress tolerance in spring wheat genotypes. Indian Journal of Advances in Chemical Sciences, 5-21/2511-2520.

Laghari, K.A., Sial, M.A., Arain, M.A. 2012. Effect of high temperature stress on grain yield components of wheat. Science, Technology and Development, 31: 83-90.

Leishman, M.R., Westoby, M. 1994. The role of seed size in seedling establishment in dry soil conditions -experimental evidence from semi-arid species. Journal of Ecology, 82: 249-258.

Lichtentharler, H.K. 1998. The stress concept in plant: an introduction. In: Stress of Life: from Molecules to Man. P. Csermely.(ed.) Annals of New York Academy Sciences, 851: 187-198.

Lobell, D.B., Monasterio, O. 2007. Impact of day versus night temperature on spring wheat yields: A comparison of empirical and ceres model predictions in three locations. Journal of Agronomy, 99: 469-477.

Mahan, J.R., McMichael, B.L., Wanjura, W.F. 1995. Methods of reducing the adverse effects of temperature stress on plants: a review. Environmental and Experimental Botany, 35: 251-258.

Modarresi, M., Mohammdi, V., Zali, A., Mardi, M. 2010. Response of wheat yield and yield related traits of high temperature. Cereal Research Communications, 38: 23-31.

Monclus, R., Dreyer, E., Villar, M., Delmotte, F.M., Delay, D., Petit, J.M., Barbaroux, C., Le Thiec, D., Brechet, C., Brignolas, F. 2006. Impact of drought on productivity and water use efficiency in 29 genotypes of populus deltoids x Populous nigra. New Phytologist, 169: 765-777.

Mukhtar, A., Hassan, F. 2011. Cumulative effect of temperature and solar radiation on wheat yield. Notulae Botanicae Horti Agrobotanica, 39: 146152.

Okçu, G., Kaya, M.D., Atak, M. 2005. Effects of salt and drought stresses on germination and seedling growth of pea (Pisum sativum L.). Turkish Journal of Agriculture and Forestry, 29: 237-242.

Parera, C.A., Cantliffe, D.J. 1994. Pre-sowing seed priming. Horticultural, 6: 109-141.

Penning, D.V., Witlage, J.M., Kremer, D. 1979. Rate of respiration and increase in structural dry matter in young wheat, ryegrass and maize plants in relation to temperature, to water stress and to their sugar content. Annals of Botany, 44: 595-609.

Rao, D.G., Sinha, S.K. 1993. Efficiency of mobilization of seed reserves in sorghum hybrids and their parents as influenced by temperature regimes. Seed Research, 2: 97-100.

Roza, G., Khayatnezhad, M., Jamaati, S.S., Zabihi, M.R. 2010. Effects of polyethylene glycol and $\mathrm{NaCl}$ stress on two cultivars of wheat (Triticum durum) at germination and early seedling stages. AmericanEurasian Journal of Agricultural and Environmental Sciences, 9: 86-90.

Sikder, S., Paul, N.K. 2010. Study of influence of temperature regimes on germination characteristics and seed reserves mobilization in wheat. African Journal of Plant Sciences, 4: 401-408.

Sikder, S., Ahmed, J.U. 2007. Mobilization of seed reserves in wheat varieties as influenced by temperature regimes. Journal of Asiatic Society of Bangladesh Science, 33: 29-35.

Tahir, I.S.A., Nakata, N., Yamaguchi, T., Nakano, J., Ali, A.M. 2008. Influence of high shoot and rootzone temperatures on growth of three wheat genotypes during early vegetative stage. Journal of Agronomy and Crop Sciences, 194: 141-151.

Walters, C. 1998. Understanding the mechanisms and kinetics of seed ageing. Seed Science Research, 8: 223-244.

Wanjura, D.F., Buxtor, D.R.1972. Hypocotyl and radical elongation of cotton as affected by soil environment. Journal of Agronomy, 64: 431-435.

Zhixia. N., Jiang, A., Hammad, W.A., Atena, O., Steven, S.X., Mergoum, M., Elias, E.M. 2014. Review of doubled haploid production in durum and common wheat through wheat 3 maize hybridization. Plant Breeding, 133: 313-320. 